\title{
Inhibition by Transforming Growth Factor- $\beta 1$ of the Cellular Action of Arginine Vasopressin in Cultured Rat Glomerular Mesangial Cells
}

\author{
Minori Higashiyama, San-e Ishikawa, Takako Saito, Tomoatsu Nakamura, Ikuyo Kusaka, \\ Shoichiro Nagasaka, Kazufumi Honda, and Toshikazu Saito
}

\begin{abstract}
The present study was undertaken to determine whether transforming growth factor (TGF)- $\beta 1$ modulates the cellular actions of arginine vasopressin (AVP) in cultured rat glomerular mesangial cells. AVP increased cytosolic free calcium $\left(\left[\mathrm{Ca}^{2+}\right] \mathrm{i}\right)$, and TGF- $\beta 1$ dose-dependently reduced the AVP-mobilized $\left[\mathrm{Ca}^{2+}\right]$ i. Such an inhibition by exogenous TGF- $\beta 1$ was abolished by liposomal transfection of antisense oligodeoxynucleotide for the TGF- $\beta$ type II receptor. AVP activated mitogen-activated protein (MAP) kinase, which was significantly reduced by $1 \mathrm{ng} / \mathrm{ml}$ TGF- $\beta 1$. AVP increased $\left[{ }^{3} \mathrm{H}\right]$ thymidine incorporation into mesangial cells in a dose-dependent manner, and $1 \mathrm{ng} / \mathrm{ml}$ TGF- $\beta 1$ significantly reduced the AVP-stimulated $\left[{ }^{3} \mathrm{H}\right]$ thymidine incorporation. However, $10 \mu \mathrm{M}$ antisense oligodeoxynucleotide for the TGF- $\beta$ type II receptor seemed to attenuate the inhibition by TGF- $\beta 1.1 \times 10^{-7} \mathrm{M}$ AVP significantly increased inositol 1,4,5-trisphosphate $\left(I_{3}\right)$ production by 1.8 -fold, but this production was totally blunted by $1 \mathrm{ng} / \mathrm{ml}$ TGF- $\beta 1$. TGF- $\beta 1$ did not affect $\left[{ }^{3} \mathrm{H}\right] \mathrm{AVP}$ receptor binding. $1 \times 10^{-6} \mathrm{M}$ AVP concentration stimulated TGF- $\beta 1$ production in mesangial cells by 4 -fold. These results indicate that TGF- $\beta 1$ inhibits the cellular signaling of AVP at steps beyond the AVP receptors and prior to the phospholipase C activation, and that TGF- $\beta 1$ may participate in a negative feedback regulation on the cellular action of AVP in glomerular mesangial cells. (Hypertens Res 1999; 22: 173-180)
\end{abstract}

Key Words: transforming growth factor (TGF)- $\beta 1$, arginine vasopressin, mesangial cells, transforming growth factor (TGF)- $\beta$ receptor

Arginine vasopressin (AVP) promotes the cellular growth of mesangial cells and vascular smooth muscle cells $(1,2)$. Such a proliferative action of AVP is mediated through phospholipase $\mathrm{C}$ activation and a series of phosphatidylinositol hydrolysis resulting in the accumulation of inositol 1,4,5-trisphosphate $\left(\mathrm{IP}_{3}\right)$ and diacylglycerol $(3,4)$. Diacylglycerol activates protein kinase $\mathrm{C}$ with a subsequent phosphorylation of mitogen-activated protein (MAP) kinase that plays a key role in the signal transduction of AVP-induced cellular growth $(5,6)$.

Glomerular mesangial cells produce transforming growth factor (TGF)- $\beta 1$ in both a normal state and diseased states showing mesangial cell proliferation $(7,8)$. TGF- $\beta 1$ plays a pathological role in the accumulation of extracellular matrix in glomerular mesangium $(7,9)$. Moreover, TGF- $\beta 1$ has been shown to inhibit proliferative response in glomerular mesangial cells $(8,10,11)$, although there have been some conflicting results regarding this proliferation $(11,12)$. The blockade of TGF- $\beta 1$ attenuates the glomerulosclerotic change (13). Such a TGF- $\beta 1$-mediated glomerulosclerosis is mimicked in response to treatment with a vasoconstrictor hormone, angiotensin II, through an effect independent of its hemodynamic action (14). Angiotensin II increases the production of TGF- $\beta 1$, which causes the accumulation of extracellular matrix in glomerular mesangium (14). Angiotensin II converting enzyme inhibitors and angiotensin II receptor antagonists relieve renal disease progression to glomerulosclerosis both in animal models and in human studies $(15,16)$. AVP acts on glomerular mesangial cells via its own $\mathrm{V}_{1 \text { a }}$ receptors and exerts an effect quite similar to that of angiotensin II $(4,5,17,18)$. However, there have been no studies on the interaction of TGF- $\beta 1$ with AVP to modulate its signal transduction in glomerular mesangial cells.

The present study was undertaken to determine whether AVP induces TGF- $\beta 1$ production in mesangial cells, and whether TGF- $\beta 1$ in turn regulates the cellular signaling of AVP.

From the Division of Endocrinology and Metabolism, Department of Medicine, Jichi Medical School, Tochigi, Japan.

This study was supported by grants from the Ministry of Education, Science, arid Culture of Japan.

Address for Reprints: San-e Ishikawa, M.D., Division of Endocrinology and Metabolism, Department of Medicine, Jichi Medical School, 3311-1 Yakushiji, Minamikawachi-machi, Tochigi 329-0498, Japan.

Received February 19, 1999; accepted in revised form April 23, 1999. 


\section{Materials and Methods}

\section{Cell Culture}

The experimental procedure was similar to that described in our previous reports (19), modified from the method of Burlington and Cronkite (20) and Scharschmidt and Dunn (21). Male Sprague-Dawly rats weighing $150-175 \mathrm{~g}$ were used. Kidneys were removed under sterile conditions. Renal cortical tissues were cut away from the medulla and minced in physiological saline solution (PSS: $140 \mathrm{mM} \mathrm{NaCl}$, $4.6 \mathrm{mM} \mathrm{KCl}, 1 \mathrm{mM} \mathrm{MgCl}, 2 \mathrm{mM} \mathrm{CaCl}, 10 \mathrm{mM}$ glucose, and $10 \mathrm{mM}$ HEPES, $\mathrm{pH} 7.4$ ) by a sharp razor blade. The minced renal cortical tissues were digested with 3 -ml PSS containing collagenase (1 $\mathrm{mg} / \mathrm{ml}$; Worthington Biochemicals, Freehold, N.J.) for $60 \mathrm{~min}$ at $37^{\circ} \mathrm{C}$. After centrifuging at $500 \times g$ for $4 \mathrm{~min}$ at room temperature, the pellets were resuspended with Dulbecco's Modified Eagle's Medium (DMEM: Flow Laboratories, McLean, VA) supplemented with $20 \%$ fetal bovine serum (FBS), 100 $\mathrm{U} / \mathrm{ml}$ penicillin, and $100 \mu \mathrm{g} / \mathrm{ml}$ streptomycin. The dispersed glomeruli were harvested into $35 \times 10-\mathrm{mm}$ plastic dishes with the medium and kept in a humidified incubator at $37^{\circ} \mathrm{C}$ under $95 \%$ air and $5 \%$ $\mathrm{CO}_{2}$. It has been well established using immunocytochemical and morphological criteria that most of the cells obtained by this culture technique are mesangial cells $(4,21,22)$. The observation under phase-contrast microscope revealed that the cells were morphologically similar to the cultured mesangial cells reported by others $(4,20,21)$, i.e., flat polygonal cells with processes showing multilayer growing. However, it could not be confirmed that the present cultured glomerular cells were pure, and they may also have contained vascular endothelial cells and podocytes.

After the mesangial cells grew confluent, they were passaged with $\mathrm{Ca}^{2+}$ - and $\mathrm{Mg}^{2+}$-free Hank's solution containing $0.025 \%$ trypsin and $0.01 \%$ EDTA. The dispersed cells were collected into culture tubes and centrifuged at $500 \times g$ for $5 \mathrm{~min}$ at room temperature. The pellets were resuspended in DMEM containing $20 \%$ FBS, penicillin, and streptomycin and were cultured in the incubator. The cells at 3 rd-10th passages were subjected to the following studies on days 7-10 of subculture.

For measurement of cellular free calcium concentration $\left(\left[\mathrm{Ca}^{2+}\right] \mathrm{i}\right)$, cells were grown on thin glass slides (13-mm in diameter; Matsunami Kogyo Co., Osaka, Japan). In addition, the cells were grown on $35 \times 10-\mathrm{mm}$ plastic dishes to study AVP receptor binding, $\mathrm{IP}_{3}$ production, and MAP kinase activity, on $100 \times 10-\mathrm{mm}$ plastic dishes to study TGF- $\beta 1$ production, and on 24-well tissue culture clusters (Costar, Cambridge, MA) for a $\left[{ }^{3} \mathrm{H}\right]$ thymidine incorporation assay.

\section{Oligodeoxynucleotide (ODN) and Liposomal Trans- fection}

The phosphorothioate antisense ODN (5'-GAG CAG CCC CCG ACC CAT-3') and sense ODN (5'-ATG GGT CGG GGG CTG CTC-3') corre- sponding to the translation initiation site of rat TGF$\beta$ type II receptor (23) were synthesized by Takara (Otsu, Japan). Liposomal transfection was performed using DOTAP (Boehringer Mannheim, Germany) according to the manufacturer's instructions with some modification. ODN was dissolved in TE buffer (10 mM Tris $\mathrm{HCl}, 1 \mathrm{mM}$ EDTA, $\mathrm{pH} 8.0)$ at a concentration of $1 \mathrm{nmol} / \mu \mathrm{l}$. For measurement of $\left[\mathrm{Ca}^{2+}\right] \mathrm{i}$, subconfluent cells grown on a 24-well tissue culture cluster were prepared. Upon pretreatment, for each well, $10-\mu$ l ODN was mixed with 10$\mu \mathrm{l}$ HEPES $(20 \mathrm{mM}, \mathrm{pH} 7.4)$, and $6 \mu \mathrm{l}$ of DOTAP was diluted in 10- $\mu$ l HEPES (20 mM, pH 7.4). These two solutions were mixed by gently pipetting, and were incubated for $15 \mathrm{~min}$ at room temperature. Thereafter, $1 \mathrm{ml}$ of the fresh medium was added into the ODN/DOTAP mixture and sterilized by filtration. The final concentrations of ODN and DOTAP were $10 \mu \mathrm{M}$ and $6 \mu \mathrm{g} / \mathrm{ml}$, respectively. The cells were exposed to $1 \mathrm{ml}$ of the filtered medium containing ODN/DOTAP mixture for $24 \mathrm{~h}$, followed by an additional 24-h incubation in the presence or absence of TGF- $\beta 1$ (R\&D Systems, Inc., Minneapolis, MN). The treatment with the antisense ODN for TGF- $\beta$ type II receptor reduced the expression of TGF- $\beta$ receptor in a western blot analysis (data not shown).

\section{Measurement of $\left[\mathrm{Ca}^{2+}\right] i$}

The experimental procedure was similar to that described in our previous reports $(24,25)$. Cells were preincubated with the medium containing 0.01-1 $\mathrm{ng} / \mathrm{ml}$ TGF- $\beta 1$ for the indicated hours. The cells were then rinsed twice with 1-ml PSS and loaded with $5 \mu \mathrm{M}$ fura-2/AM (Dojin Biochemicals, Kumamoto, Japan) in a volume of $0.25 \mathrm{ml}$ for $60 \mathrm{~min}$ at $37^{\circ} \mathrm{C}$. After aspiration of the fura-2/AM solution, the glass slide was rinsed and placed in a $1 \times 1-\mathrm{cm}$ quartz cuvette with the aid of special holder in a fluorescence spectrophotometer (CAF-100, Japan Spectroscopic Co., Tokyo, Japan). The dual wavelength excitation method was used for measurement of fura-2 fluorescence. The fluorescence was monitored at $500 \mathrm{~nm}$ with excitation wavelengths of 340 and $380 \mathrm{~nm}$ in the ratio mode. AVP (Sigma Chemical Co., St. Louis, MO) was added after a stable fluorescence signal (R) was achieved. From the ratio of the fluorescence at 340 and $380 \mathrm{~nm}$, the $\left[\mathrm{Ca}^{2+}\right] \mathrm{i}$ was determined as described by Grynkiewicz et al. (26), using the following expression: $\left[\mathrm{Ca}^{2+}\right] \mathrm{i}(\mathrm{nM})=\mathrm{Kd} \times[(\mathrm{R}-\mathrm{Rmin}) /(\mathrm{Rmax}-\mathrm{R})] \times \beta$, where $R$ is the ratio of fluorescence of the sample at 340 and $380 \mathrm{~nm}$, and Rmax and Rmin are obtained by treating the cells with $5 \times 10^{-5} \mathrm{M}$ digitonin and $1 \times 10^{-2} \mathrm{M} \mathrm{MnCl}_{2}$, respectively. The term $\beta$ is the ratio of the fluorescence of fura- 2 at $380 \mathrm{~nm}$ in zero and saturating $\mathrm{Ca}^{2+}$ concentrations. $\mathrm{Kd}$ is the dissociation constant of fura- 2 for $\mathrm{Ca}^{2+}$, assumed to be $224 \mathrm{nM}$ at $37^{\circ} \mathrm{C}(26)$.

The experiment was also performed in cells liposomally transfected with the antisense or sense ODN for TGF- $\beta$ type II receptor. Twenty-four hours after lipofection, $1 \mathrm{ng} / \mathrm{ml}$ TGF- $\beta 1$ was added into the medium, and the cells were incubated for 
another $24 \mathrm{~h}$. Thereafter the cells were subjected to the measurement of $\left[\mathrm{Ca}^{2+}\right] \mathrm{i}$.

\section{MAP Kinase Assay}

MAP kinase activity was determined by phosphorylation of myelin basic protein (MBP) as described previously $(1,27)$. Cells grown on $35 \times 10-\mathrm{mm}$ dishes were incubated with serum-free DMEM in the presence or absence of $1 \mathrm{ng} / \mathrm{ml}$ TGF- $\beta 124 \mathrm{~h}$ before the start of the experiments. After rinsing twice with $2 \mathrm{ml}$ of PSS, the cells were stimulated for 5 min at $37^{\circ} \mathrm{C}$ with $1 \mathrm{ml}$ of $1 \times 10^{-6} \mathrm{M}$ AVP or phorbol-12-myristate-13-acetate (PMA, Sigma). After aspiration of the stimulants, the cells were exposed to $0.5 \mathrm{ml}$ of the solution containing $20 \mathrm{mM}$ Tris, $5.6 \mathrm{mM} \beta$-glycerophosphate, $10 \mathrm{mM}$ EGTA, $10 \mathrm{mM} \mathrm{MgCl}, 0.1 \mathrm{mM} \mathrm{NaF}, 2 \mathrm{mM}$ DTT, $1 \mathrm{mM}$ $\mathrm{NaVO}_{3}, 20 \mu \mathrm{g} / \mathrm{ml}$ aprotinin, and $1 \mathrm{mM}$ PMSF, pH 7.5. Thereafter, the dishes were immediately put onto dry ice. After centrifugation, the supernatants were kept at $-20^{\circ} \mathrm{C}$ until the time of assay.

Glass tubes containing $60 \mu \mathrm{l}$ of assay mixture [40 $\mathrm{mM}$ Tris, $40 \mathrm{mM} \mathrm{MgCl}, 2.5 \mathrm{mg} / \mathrm{ml}$ MBP (Sigma), $0.5 \mathrm{mM}$ ATP, and $0.5 \mu \mathrm{Ci}{ }^{32} \mathrm{P}-\gamma \mathrm{ATP}$ (specific activity, $>10 \mathrm{Ci} / \mathrm{mM}$; New England Nuclear, Wilmington, DE)] were incubated at $25^{\circ} \mathrm{C}$ for $10 \mathrm{~min}$. Next, $40 \mu \mathrm{l}$ of samples were added, and the mixtures were incubated for an additional $10 \mathrm{~min}$ at $25^{\circ} \mathrm{C}$. The mixtures were transferred onto glass microfiber filters (2.4-cm GF/C; Whatman, Maidstone, England) with disposable plastic chips. The filters were then put into ice-cold $10 \%$ trichloroacetic acid containing $50 \mathrm{mM}$ sodium pyrophosphate and shaken gently for $20 \mathrm{~min}$ to remove free ${ }^{32} \mathrm{P}-\gamma \mathrm{ATP}$. This maneuver was repeated four times. After that, the filters were immersed in ice-cold ethanol for $20 \mathrm{~min}$ and then exposed to diethylether. The washed filters were put into counting vials containing $10 \mathrm{ml}$ of scintillation solution, and the radioactivity was measured with a liquid scintillation counter (Aloka LSC-671, Tokyo Japan). The cellular protein content was also measured by the method of Lowry et al. (28).

\section{Measurement of Thymidine Incorporation}

The cells grown to confluence on a 24-well tissue culture cluster were synchronized to the quiescent state by incubation with $1 \mathrm{ml}$ of serum-free DMEM for $24 \mathrm{~h}$. In addition, the cells were transfected with the antisense or sense ODN for the TGF- $\beta$ type II receptor in serum-free DMEM, as described above. The cells were then stimulated with $1 \times 10^{-9}-10^{-6}$ M AVP in $1 \mathrm{ml}$ of serum-free DMEM, in the absence or presence of $1 \mathrm{ng} / \mathrm{ml}$ TGF- $\beta 1$. The cells were incubated for an additional $24 \mathrm{~h}$ at $37^{\circ} \mathrm{C}$ and loaded with $\left[{ }^{3} \mathrm{H}\right]$ thymidine $(2 \mu \mathrm{Ci} /$ well; specific activity, $80.8 \mathrm{Ci} / \mathrm{mM}$; New England Nuclear) for the last $6 \mathrm{~h}$. Thereafter, the cells were rinsed three times with PSS and immersed with $0.5 \mathrm{ml}$ of $10 \%$ trichloroacetic acid. The cells were collected into counting vials with disposable plastic chips, and $10 \mathrm{ml}$ of scintillation solution was then added. The radioactivity was measured with the liquid scintillation counter (Alo$\mathrm{ka})$. The protein concentration was also measured by the method of Lowry et al. (28).

\section{AVP Receptor Binding Assay}

The experimental procedure for this assay was similar to that described previously $(1,29)$. The cells grown on $35 \times 10-\mathrm{mm}$ plastic dishes were exposed to the medium containing $1 \mathrm{ng} / \mathrm{ml}$ TGF- $\beta 1$ or the vehicle $24 \mathrm{~h}$ before the start of the experiments. The cells were rinsed twice with 2-ml ice-cold binding buffer $(119.2 \mathrm{mM} \mathrm{NaCl}, 3.0 \mathrm{mM} \mathrm{KCl}, 1.2 \mathrm{mM}$ $\mathrm{MgSO}_{4}, 1.0 \mathrm{mM} \mathrm{CaCl} 2,1.2 \mathrm{mM} \mathrm{KH} \mathrm{KO}_{4}, 10 \mathrm{mM}$ glucose, and $25 \mathrm{mM}$ HEPES, as well as $0.1 \%$ bovine serum albumin, $\mathrm{pH}$ 7.4). The cells were then incubated with 1-ml ice-cold binding buffer containing $2 \times 10^{-9} \mathrm{M}\left[{ }^{3} \mathrm{H}\right] \mathrm{AVP}$ (specific activity 67.6 $\mathrm{Ci} / \mathrm{mM}$; New England Nuclear) in the absence or presence of cold AVP at $4^{\circ} \mathrm{C}$ for $60 \mathrm{~min}$ with or without $1 \mathrm{ng} / \mathrm{ml}$ TGF- $\beta 1$. After incubation, the cells were rinsed four times with $2 \mathrm{ml}$ of ice-cold binding buffer, followed by the addition of $1 \mathrm{ml}$ of $0.1 \mathrm{~N}$ $\mathrm{NaOH}$ containing $1 \%$ sodium dodecylsulfate. The radioactivity was measured with the liquid scintillation counter (Aloka). The protein concentration was measured by the method of Lowry et al. (28).

\section{Measurement of Inositol Trisphosphate}

The experimental procedure was similar to that reported in our previous study $(30)$. The cells grown on $35 \times 10-\mathrm{mm}$ dishes were used. These cells were washed twice and incubated with $1 \mathrm{ml}$ of inositolfree DMEM containing $5 \mu \mathrm{Ci} / \mathrm{ml}\left[\mathrm{myo}^{-3} \mathrm{H}\right]$ inositol (specific activity, $19.1 \mathrm{Ci} / \mathrm{mM}$, New England $\mathrm{Nu}-$ clear) in the humidified incubator for $24 \mathrm{~h}$, in the absence or presence of $0.1-1 \mathrm{ng} / \mathrm{ml}$ TGF- $\beta 1$. At the time of the experiment, the cells were rinsed twice with $2 \mathrm{ml}$ of PSS and then incubated with $0.8 \mathrm{ml}$ of PSS containing $1 \times 10^{-7}$ and $10^{-6} \mathrm{M}$ AVP for $10 \mathrm{~s}$. The reaction was stopped by the addition of $0.2 \mathrm{ml}$ of $50 \%$ trichloroacetic acid, and the cells were then collected with disposable plastic chips. The suspensions containing the disrupted cells were centrifuged by a microcentrifuger. The supernatants were washed 5 times with ether, and the water-soluble fractions were then brought to $\mathrm{pH} 7.0$ with $1 \mathrm{~N} \mathrm{NaOH}$ and stored at $-20^{\circ} \mathrm{C}$ until the analysis. The pellets were dissolved with $0.1 \mathrm{ml}$ of $0.1 \mathrm{~N} \mathrm{NaOH}$ containing $1 \%$ sodium dodecylsulfate and stored at $4^{\circ} \mathrm{C}$ for protein assay. The water-soluble fractions were applied to columns containing $1 \mathrm{ml}$ of Dowex $(1 \times 8$, formate form, Muromachi Kagaku Kogyo, Tokyo, Japan) and serially eluted 10 times with 2-ml aliquots of $\mathrm{H}_{2} \mathrm{O}$, Borax $(5 \mathrm{mM}$ disodium tetraborate, $60 \mathrm{mM}$ sodium formate), and $0.2,0.4$, and $1.0 \mathrm{M}$ ammonium formate in $0.1 \mathrm{M}$ formic acid. This maneuver separated inositol, glycerophosphatidylinositol, inositol-1-phosphate, inositol bisphosphate, and $\mathrm{IP}_{3}$, respectively. The $\mathrm{IP}_{3}$ fractions include 1,3,4$\mathrm{IP}_{3}, 1,4,5-\mathrm{IP}_{3}$ and inositol 1,3,4,5-tetrakisphosphate. Samples were collected into scintillation counting vials and counted with the liquid scintillation counter (Aloka).

\section{Measurement of TGF- $\beta 1$ Concentration}

The confluent cells grown on $100 \times 10$-mm culture 


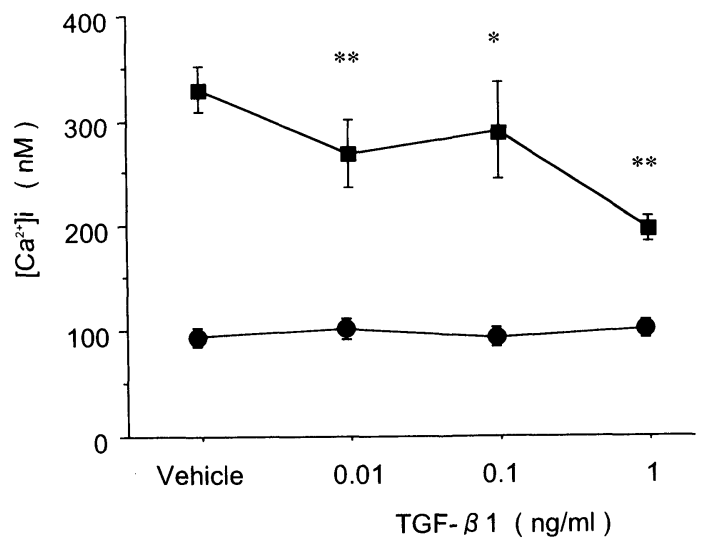

Fig. 1. Inhibition by transforming growth factor (TGF)$\beta 1$ of arginine vasopressin $(A V P)$-induced cytosolic free calcium $\left(\left[\mathrm{Ca}^{2+}\right] \mathrm{i}\right)$ increase in cultured rat glomerular mesangial cells. Closed circles (-) show basal levels of

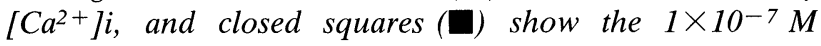
AVP-mobilized $\left[\mathrm{Ca}^{2+}\right]$ i. ${ }^{*} \mathrm{p}<0.05$ and ${ }^{* *} \mathrm{p}<0.01$ vs. the vehicle. Values are means $\pm S E M, \mathrm{n}=6$.

dishes were starved for $12 \mathrm{~h}$ with serum-free DMEM, then incubated with $1 \mathrm{ml}$ of serum-free DMEM in the absence or presence of AVP for a further $12 \mathrm{~h}$. For comparison, the cells were also incubated with DMEM containing 5\% FBS in the same manner. The concentration of TGF- $\beta 1$ in the culture media was measured with an ELISA TGF$\beta 1$ Kit (Morinaga Seikagaku Co., Yokohama, Japan) according to the manufacturer's instructions. Latent TGF- $\beta 1$ peptides were converted to the activated form by hydrochloride treatment of culture media before the assay. In brief, anti-murine TGF$\beta 1$ chicken antibody-bound microplate was serially reacted with sample media, biotinylated secondary antibody against TGF- $\beta 1$, and peroxidase-linked streptoavidin, followed by the addition of orthophenylene-diamine for visualization. The absorbance at $492 \mathrm{~nm}$ and $620 \mathrm{~nm}$ in each well was measured with a Microplate Reader (Bio-Rad, Hercules, $\mathrm{CA}$ ), and the data were analyzed using Microplate Manager III software.

\section{Statistics}

All values of $\left[\mathrm{Ca}^{2+}\right] \mathrm{i}$, MAP kinase activity, $\left[{ }^{3} \mathrm{H}\right]-$ thymidine incorporation, $\mathrm{IP}_{3}$ and TGF- $\beta 1$ concentration were analyzed by an analysis of variance and a Student's $t$-test. $P$ value of less than 0.05 was considered significant.

\section{Results}

Figure 1 shows the effects of TGF- $\beta 1$ on the AVPinduced increase in $\left[\mathrm{Ca}^{2+}\right] \mathrm{i}$ in cultured rat glomerular mesangial cells. AVP increased $\left[\mathrm{Ca}^{2+}\right] \mathrm{i}$ in a dose-dependent manner (19). A $1 \times 10^{-7} \mathrm{M}$ concentration of AVP raised $\left[\mathrm{Ca}^{2+}\right] \mathrm{i}$ from $90.7 \pm 5.5$ to $325.6 \pm 21.8 \mathrm{nM}(p<0.01)$. When cells were preincubated for $24 \mathrm{~h}$ with TGF- $\beta 1$, the $1 \times 10^{-7} \mathrm{M}$ AVP-induced increase in $\left[\mathrm{Ca}^{2+}\right] \mathrm{i}$ was significantly

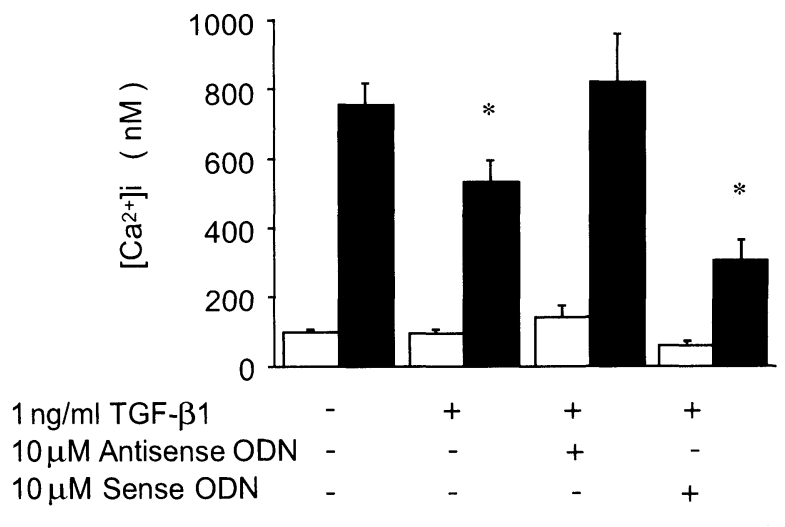

Fig. 2. Effect of antisense oligodeoxynucleotide (ODN) for transforming growth factor (TGF)- $\beta$ type II receptor on arginine vasopressin $(A V P)$-induced cytosolic free calcium $\left(\left[\mathrm{Ca}^{2+}\right] \mathrm{i}\right)$ in cultured rat glomerular mesangial cells. Open bars show basal levels, and solid bars show the $1 \times$ $10^{-7} M A V P$-induced $\left[\mathrm{Ca}^{2+}\right] i$. $* \mathrm{p}<0.05$ vs. the vehicle. Values are means $\pm S E M, \mathrm{n}=4$.

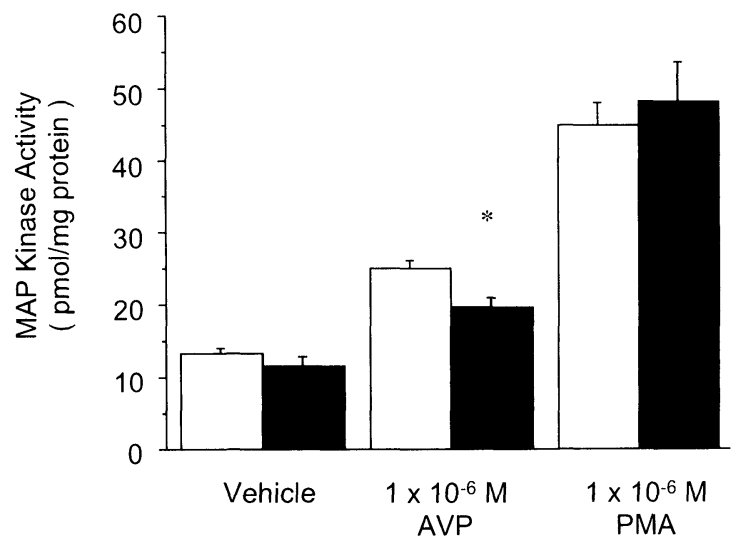

Fig. 3. Inhibition by transforming growth factor (TGF)$\beta 1$ of arginine vasopressin (AVP)-induced mitogen-activated protein (MAP) kinase activity in cultured rat glomerular mesangial cells. Open bars show control group, and solid bars show the $1 \mathrm{ng} / \mathrm{ml}$ TGF- $\beta 1$ group. ${ }^{*} \mathrm{p}<0.05$ vs. the control. Values are means $\pm S E M, \mathrm{n}=6$.

reduced in a dose-dependent manner $(1 \mathrm{ng} / \mathrm{ml}$ TGF$\beta 1 ; 190.0$ vs. $325.6 \mathrm{nM}, p<0.01)$. TGF- $\beta 1$ did not affect the basal $\left[\mathrm{Ca}^{2+}\right]$ i. Such an inhibition by TGF$\beta 1$ of the AVP-induced increase in $\left[\mathrm{Ca}^{2+}\right] \mathrm{i}$ was obtained in response to a more than $4-h$ incubation (data not shown). Figure 2 shows that the antisense ODN for TGF- $\beta$ type II receptor restored the AVP-induced $\left[\mathrm{Ca}^{2+}\right] \mathrm{i}$ in the presence of TGF- $\beta 1.1$ $\times 10^{-7} \mathrm{M}$ AVP significantly increased $\left[\mathrm{Ca}^{2+}\right] \mathrm{i}$. In addition, $1 \mathrm{ng} / \mathrm{ml}$ TGF- $\beta 1$ significantly reduced the AVP-induced $\left[\mathrm{Ca}^{2+}\right]$ i. However, pretreatment with $10 \mu \mathrm{M}$ antisense ODN for the TGF- $\beta$ type II receptor restored the AVP-mobilized $\left[\mathrm{Ca}^{2+}\right] \mathrm{i}$. There was no significant change in $\left[\mathrm{Ca}^{2+}\right] \mathrm{i}$ in a group of cells treated with the sense ODN. 


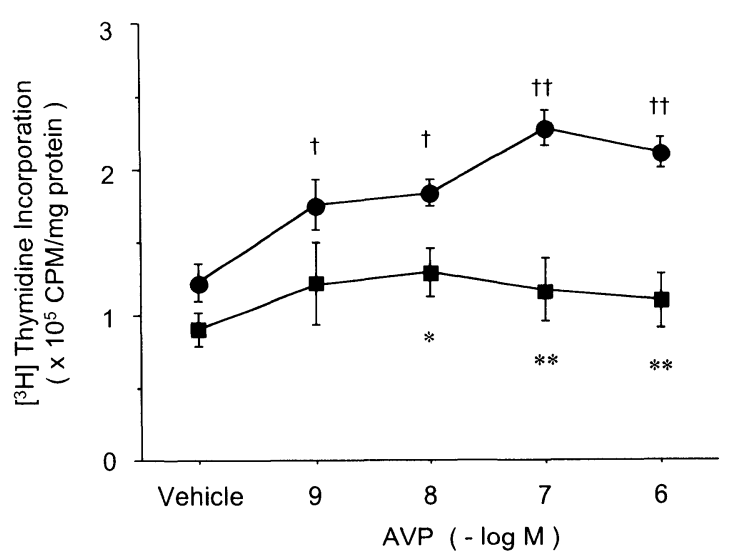

Fig. 4. Inhibition by transforming growth factor (TGF)$\beta 1$ of arginine vasopressin $(A V P)$-induced $\left[{ }^{3} H\right]$ thymidine incorporation into cultured rat glomerular mesangial cells. Closed circles (O) show the control group, and closed

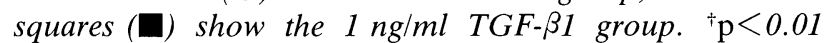
and ${ }^{+{ }^{+}} \mathrm{p}<0.005$ vs. the vehicle. ${ }^{*} \mathrm{p}<0.05$ and $* * \mathrm{p}<0.01$ vs. the control group. Values are means $\pm S E M, \mathrm{n}=4$.

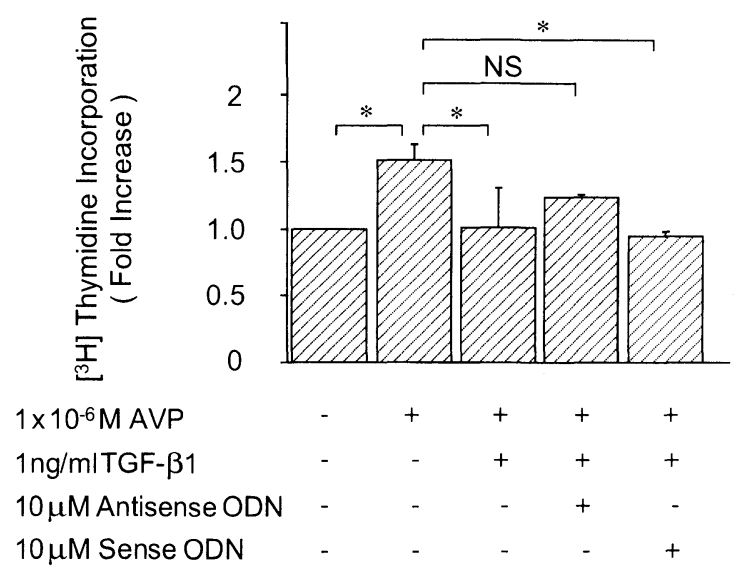

Fig. 5. Effect of antisense oligodeoxynucleotide (ODN) for transforming growth factor (TGF)- $\beta$ type II receptor on arginine vasopressin (AVP)-stimulated $\left[{ }^{3} H\right]$ thymidine incorporation into cultured rat glomerular mesangial cells. Values show as a fold increase. ${ }^{*} \mathrm{p}<0.05$. Mean $\pm S E M$, $\mathrm{n}=4$.

The effects of TGF- $\beta 1$ on MAP kinase activity in cultured rat glomerular mesangial cells is shown in Fig. 3. TGF- $\beta 1$ per se did not affect the basal activity of MAP kinase. The $1 \times 10^{-6} \mathrm{M}$ AVP-activated MAP kinase was reduced by a 24-h exposure to 1 $\mathrm{ng} / \mathrm{ml}$ TGF- $\beta 1(p<0.05)$. In contrast, the activation of MAP kinase by $1 \times 10^{-6} \mathrm{M}$ PMA was not affected by the presence of TGF- $\beta 1$.

Figure 4 depicts the effects of AVP and TGF- $\beta 1$ on $\left[{ }^{3} \mathrm{H}\right]$ thymidine incorporation into cultured rat glomerular mesangial cells. $1 \times 10^{-7} \mathrm{M}$ AVP increased this incorporation from $1.23 \pm 0.13$ to 2.29 $\pm 0.12 \times 10^{5} \mathrm{CPM} / \mathrm{mg}$ protein $(p<0.005)$. Coincubation of $1 \mathrm{ng} / \mathrm{ml}$ TGF- $\beta 1$ with AVP significantly blunted the AVP-stimulated $\left[{ }^{3} \mathrm{H}\right]$ thymidine incor-

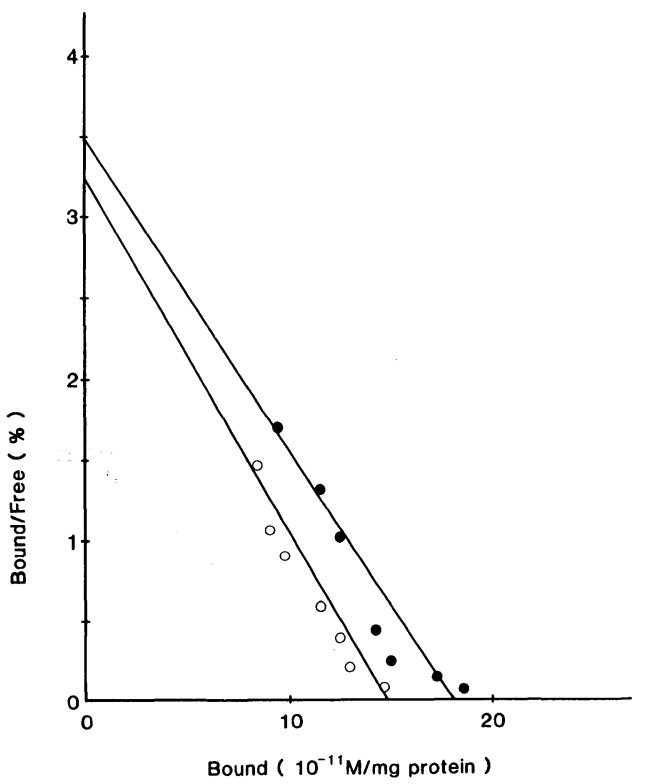

Fig. 6. Scatchard analysis of $\left[{ }^{3} H\right]$ arginine vasopressin (AVP) binding to cultured rat glomerular mesangial cells. Open circles (O) show the study in intact cells, and closed circles (-) show the study in cells treated with $1 \mathrm{ng} / \mathrm{ml}$ transforming growth factor $(T G F)-\beta 1$.

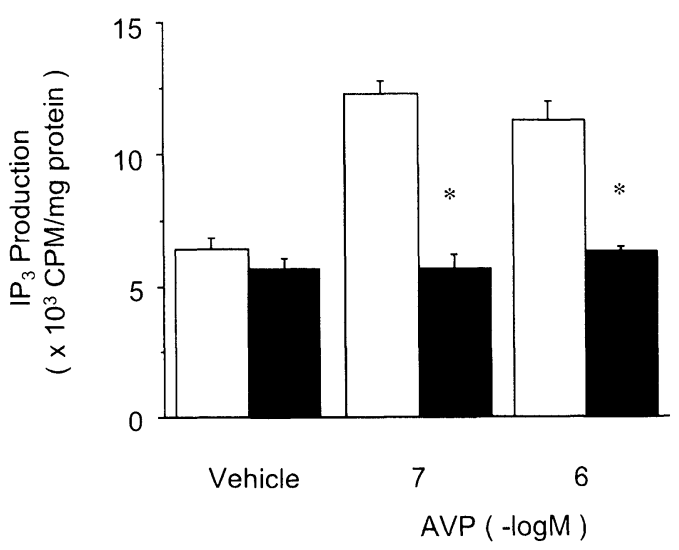

Fig. 7. Inhibition by transforming growth factor (TGF)B1 of arginine vasopressin (AVP)-induced inositol 1,4,5trisphosphate $\left(I P_{3}\right)$ production in cultured rat glomerular mesangial cells. Open bars show the control group. Solid bars show the group of cells pretreated for $24 \mathrm{~h}$ with 1 $n g / m l T G F-\beta 1 .{ }^{*} \mathrm{p}<0.01$ vs. the control group. Values are means $\pm S E M, \mathrm{n}=3$.

poration. Figure 5 shows the effects of antisense ODN for the TGF- $\beta$ type II receptor on $\left[{ }^{3} \mathrm{H}\right]$ thymidine incorporation into cultured rat glomerular mesangial cells. $1 \times 10^{-6} \mathrm{M}$ AVP increased $\left[{ }^{3} \mathrm{H}\right]-$ thymidine incorporation, and the presence of 1 $\mathrm{ng} / \mathrm{ml}$ TGF- $\beta 1$ significantly reduced its incorporation. However, pretreatment with $10 \mu \mathrm{M}$ antisense ODN seemed to restore the suppression by TGF- $\beta 1$ of the AVP-stimulated $\left[{ }^{3} \mathrm{H}\right]$ thymidine incorpora- 


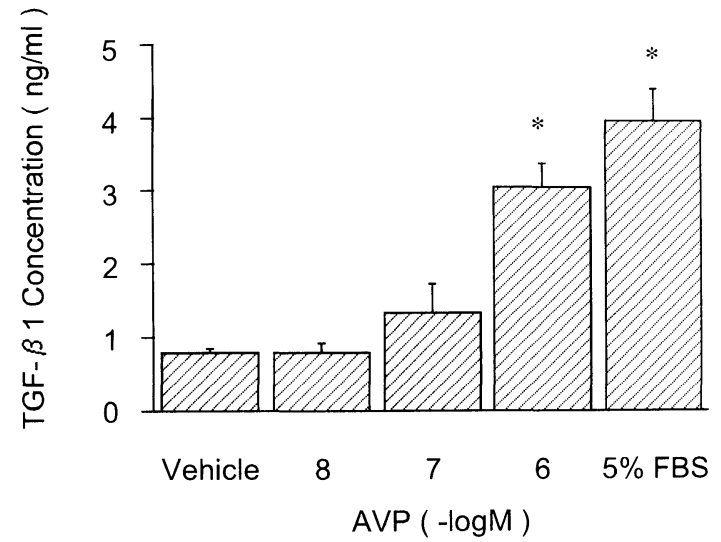

Fig. 8. Arginine vasopressin (AVP) and $5 \%$ fetal bovine serum (FBS) increase transforming growth factor (TGF)$\beta 1$ production in cultured rat glomerular mesangial cells. $* \mathrm{p}<0.005$ vs. the vehicle. Values are means $\pm S E M, \mathrm{n}=4$.

tion.

The scatchard analysis of $\left[{ }^{3} \mathrm{H}\right]$ AVP binding to cultured rat glomerular mesangial cells is shown in Fig. 6. There is a single class of receptor of AVP. $\mathrm{Kd}$ and $\mathrm{Bmax}$ were $5 \times 10^{-11} \mathrm{M}$ and $1.76 \times 10^{-10}$ $\mathrm{M} / \mathrm{mg}$ protein in the intact cells, respectively. Pretreatment with $1 \mathrm{ng} / \mathrm{ml}$ TGF- $\beta 1$ did not alter the binding of $\left[{ }^{3} \mathrm{H}\right]$ AVP to glomerular mesangial cells.

Inhibition by TGF- $\beta 1$ of AVP-induced $\mathrm{IP}_{3}$ production in cultured rat glomerular mesangial cells is presented in Fig. 7. AVP at concentrations of $1 \times$ $10^{-7}$ and $1 \times 10^{-6} \mathrm{M}$ significantly increased $\mathrm{IP}_{3}$ production by 1.7-1.8-fold. Such an increase in $\mathrm{IP}_{3}$ production by AVP was totally abolished by 0.1 and $1 \mathrm{ng} / \mathrm{ml}$ TGF- $\beta 1(0.1 \mathrm{ng} / \mathrm{ml}$ TGF- $\beta 1$ study; data not shown). TGF- $\beta 1$ per se did not alter the basal $\mathrm{IP}_{3}$ production.

The effects of AVP on TGF- $\beta 1$ production in cultured rat glomerular mesangial cells are shown in Fig. 8. TGF- $\beta 1$ concentration in the media seemed to be dose-dependently increased by AVP. $1 \times 10^{-6}$ M AVP increased TGF- $\beta 1$ by approximately 4-fold $(p<0.005)$, to a level comparable to that induced by the presence of $5 \%$ FBS.

\section{Discussion}

The present study demonstrated that AVP-induced cellular signal transduction is inhibited by TGF- $\beta 1$ without any alteration in AVP binding to the receptors, and also that AVP per se increases TGF- $\beta 1$ production in cultured rat glomerular mesangial cells. These results suggest that TGF- $\beta 1$ may play a specific role in negatively controlling the cellular action of AVP in glomerular mesangial cells.

AVP initiates a series of phosphatidylinositol breakdowns mediated through $V_{1 a}$ receptors. These receptors have seven transmembrane domains and are coupled to $\mathrm{Gq}$ proteins in glomerular mesangial cells and their homologous cells, vascular smooth muscle cells $(1-5)$. Phosphatidylinositol hydrolysis results in an accumulation of $\mathrm{IP}_{3}$ and diacylglycerol, leading to the mobilization of $\left[\mathrm{Ca}^{2+}\right] \mathrm{i}$ from the endoplasmic reticulum and the activation of protein kinase $\mathrm{C}$, respectively $(4,5,17,18)$. AVP promotes the cellular proliferation of mesangium $(1,5,30$, 31). The activation by AVP of MAP kinase, downstream of protein kinase $C$, transduces the signal to c-fos and c-myc proteins, followed by an increase in thymidine incorporation $(1,2,22,30)$. In addition, phospholipase $\mathrm{D}$, in part, participates in the action of AVP to promote the cellular growth of glomerular mesangial cells (30). The activation of phospholipase D is dependent on protein kinase C, which is stimulated by phospholipase $\mathrm{C}$ and the hydrolysis of phosphatidylinositol AVP initiates (30).

TGF- $\beta 1$ is known to inhibit cellular growth in various types of cells $(7,8,10,11)$. In particular, TGF$\beta 1$ has been shown to have an inhibitory effect on mesangial cell growth $(7,10,11)$, though there have been some controversial results $(11,12)$. The present study showed that TGF- $\beta 1$ suppresses the activation of classical MAP kinase and $\left[{ }^{3} \mathrm{H}\right]$ thymidine incorporation induced by AVP in glomerular mesangial cells, supporting the inhibitory properties of TGF- $\beta 1$ in mesangial cell growth. Similar results have also been obtained with angiotensin II $(14,31$, 32). TGF- $\beta 1$ also reduced the AVP-induced $\mathrm{IP}_{3}$ production and $\left[\mathrm{Ca}^{2+}\right] \mathrm{i}$ mobilization, suggesting that TGF- $\beta 1$ diminishes mesangial cell contraction as well as mesangial cell DNA synthesis stimulated by AVP. There are TGF- $\beta 1$ receptors in mesangial cells (11) and the antisense method suggested that the inhibition by TGF- $\beta 1$ of AVP actions is mediated via its own receptors. The antisense ODN for the TGF- $\beta$ type II receptor reduced the expression of the receptors in glomerular mesangial cells, but the effect of the antisense ODN was not uniformly obtained. The pretreatment procedure and the time course of the response were different between the $\left[\mathrm{Ca}^{2+}\right] \mathrm{i}$ mobilization study and the $\left[{ }^{3} \mathrm{H}\right]$ thymidine incorporation assay, which could underlie the discordant effect of the antisense ODN. Our finding that $\left[{ }^{3} \mathrm{H}\right] \mathrm{AVP}$ binding to glomerular mesangial cells is not altered by TGF- $\beta 1$ indicates that TGF- $\beta 1$ exerts its inhibitory action at steps beyond the AVP receptors and prior to the phospholipase $\mathrm{C}$ either by directly or indirectly affecting the phospholipase $\mathrm{C}$ activity through the inhibition of the Gq protein itself or the receptor-G protein coupling.

Glomerular mesangial cells produce TGF- $\beta$ (7, $8)$. An excessive expression of TGF- $\beta$ in the kidney is observed in renal disorders characterized by mesangial proliferation, including IgA nephropathy, lupus nephritis, diabetic nephropathy, hypertensive renal injury, and others $(7,9,33-37)$. The pathological role of TGF- $\beta$ has been established in relation to the inhibition of cell growth $(8,10,11,32)$, in addition to the accumulation of extracellular matrix (33-37). The present study showed that AVP increases TGF- $\beta 1$ production and that the stimulatory properties of AVP in relation to cellular contraction and mitogenesis are suppressed by TGF- $\beta 1$ through a receptor-mediated effect in glomerular mesangial cells. These results thus may suggest that TGF- $\beta 1$ 
increased by AVP in turn negatively regulates the actions of AVP by an autocrine or paracrine mechanism in glomerular mesangial cells. Similar antimitogenic regulation by autocrine TGF- $\beta 1$ against mitogenic stimuli, including angiotensin II and high glucose, has been described previously $(32,38)$. In the present study, we did not examine extracellular matrix accumulation by AVP, and we could not confirm whether AVP participates in the development of glomerulopathy with mesangial proliferation. The involvement of TGF- $\beta 1$ in extracellular matrix protein synthesis has been observed with another vasoconstrictor hormone, angiotensin II: as angiotensin II enhances TGF- $\beta 1$ production in glomerular mesangial cells and the induced TGF- $\beta 1$ stimulates matrix protein synthesis, the net effect of angiotensin II is to promote extracellular matrix accumulation (14). The present study therefore indicates that there may be a negative feedback control of cellular action of AVP, mediated via the production of TGF- $\beta 1$, in glomerular mesangial cells.

\section{Acknowledgements}

The present study was presented at the 79th Annual Meeting of The Endocrine Society June 11-14, 1997, Minneapolis, Minnesota.

\section{References}

1. Ishikawa S, Kawasumi M, Okada K, Saito T: Low density lipoprotein enhances the cellular action of arginine vasopressin in rat glomerular mesangial cells in culture. J Clin Invest 1994; 93: 2710-2717.

2. Kribben A, Wieder ED, Li X, et al: AVP-induced activation of MAP kinase in vascular smooth muscle cells is mediated through protein kinase C. Am J Physiol 1993; 265: C939-C945.

3. Nambi P, Watt R, Whitman M, et al: Induction of cfos protein by activation of vasopressin receptors in smooth muscle cells. FEBS Lett 1989; 245: 61-64.

4. Mene P, Simonson MS, Dunn MJ: Physiology of the mesangial cells. Physiol Rev 1989; 69: 1347-1424.

5. Force T, Kyriakis JM, Avruch J, Bonventre JV: Endothelin, vasopressin, and angiotensin enhance tyrosine phosphorylation by protein kinase C-dependent and -independent pathways in glomerular mesangial cells. J Biol Chem 1991; 266: 6650-6656.

6. Granot Y, Erikson E, Fridman H, et al: Direct evidence fot tyrosine and threonine phosphorylation and activation of mitogen-activated protein kinase by vasopressin in cultured rat vascular smooth muscle cells. J Biol Chem 1993; 268: 9564-9569.

7. Bruijn JA, Roos A, de Geus B, de Heer E: Transforming growth factor- $\beta$ and the glomerular extracellular matrix in renal pathology. J Lab Clin Med 1994; 123: 34-47.

8. Kaname S, Uchida S, Ogata E, Kurokawa K: Autocrine secretion of transforming growth factor- $\beta$ in cultured rat mesangial cells. Kidney Int 1992; 42: 1319-1327.

9. Border WA, Noble NA: Cytokines in kidney disease: the role of transforming growth factor- $\beta$. Am J Kidney Dis 1993; 22: 105-113.

10. Jaffer F, Saunders C, Schultz P, Throchmorton D, Weinshell E, Abboud HE: Regulation of mesangial cell growth by polypeptide mitogens: inhibitory role of transforming growth factor beta. Am J Pathol 1989; 135: 261-269.

11. MacKay K, Striker LJ, Stanffer JW, Doi T, Agodoa LY, Striker GE: Transforming growth factor- $\beta$. Murine glomerular receptors and responses of isolated glomerular cells. J Clin Invest $1989 ;$ 83: 11601167.

12. Haberstroh U, Zahner G, Disser M, Thaiss F, Wolf $\mathrm{G}$, Stahl RA: TGF- $\beta$ stimulates rat glomerular cell proliferation in culture: role of PDGF- $\beta$ receptor expression. Am J Physiol 1993; 264: F199-F205.

13. Border WA, Okuda S, Languino LR, Sporn MB, Ruoslahti E: Suppression of experimental glomerulonephritis by antiserum against transforming growth factor $\beta 1$. Nature 1990; 346: 371-374.

14. Kagami S, Border WA, Miller DE, Noble NA: Angiotensin II stimulates extracellular matrix protein synthesis through induction of transforming growth factor- $\beta$ expression in rat glomerular mesangial cells. J Clin Invest 1994; 93: 2431-2437.

15. Zoja C, Abbate M, Corna D, et al: Pharmacological control of angiotensin II ameliorates renal disease while reducing renal TGF- $\beta$ in experimental mesangioproliferative glomerulonephritis. Am J Kidney Dis 1998; 31: 453-463.

16. Ritz E, Orth SR, Strzelczyk P: Angiotensin converting enzyme inhibitors, calcium channel blockers, and their combination in the treatment of glomerular disease. J Hypertens Suppl 1997; 15: S21-S26.

17. Takeda K, Meyer-Lehnert H, Kim JK, Schrier RW: AVP-induced $\mathrm{Ca}$ fluxes and contraction of rat glomerular mesangial cells. Am J Physiol 1988; 255: F142-F150.

18. Bonventre JV, Skolecki KL, Kreisberg JI, Cheung JY: Vasopressin increases cytosolic free calcium concentration in glomerular cells. Am J Physiol 1986; 251: F94-F102.

19. Ishikawa S, Okada K, Saito T: Increases in cellular sodium concentration by arginine vasopressin and endothelin in cultured rat glomerular mesangial cells. Endocrinology 1992; 131: 1429-1435.

20. Burlington $\mathrm{H}$, Cronkite EP: Characteristics of cell cultures derived from renal glomeruli. Proc Soc Exp Biol Med 1973; 142: 143-149.

21. Scharschmidt LA, Dunn MJ: Prostaglandin synthesis by rat glomerular mesangial cells in culture. Effects of angiotensin II and arginine vasopressin. J Clin Invest 1983; 71: 1756-1764.

22. Ishikawa $S$, Kawasumi $M$, Saito $T$ : Simvastatin inhibits the cellular signaling and proliferative action of arginine vasopressin in cultured rat glomerular mesangial cells. Endocrinology 1995; 136: 1954-1961.

23. Tsuchida K, Lewis KA, Mathews LS, Vale WW: Molecular characterization of rat transforming growth factor- $\beta$ type II receptor. Biochem Biophys Res Commun 1993; 191: 790-795.

24. Ishikawa S, Okada K, Saito T: Arginine vasopressin increases cellular free calcium concentration and adenosine $3^{\prime}, 5^{\prime}$-monophosphate production in rat renal papillary collection tubule cells in culture. Endocrinology 1988; 123: 1376-1384.

25. Ishikawa S, Saito T: Optimal concentration of cellular free calcium for AVP-induced cAMP in collecting tubules. Kidney Int 1990; 37: 1060-1066.

26. Grynkiewicz G, Poenie M, Tsien RY: A new generation of $\mathrm{Ca}^{2+}$ indicators with greatly improved fluorescence properties. J Biol Chem 1985; 260: 3440-3450.

27. Shirakabe K, Gotoh Y, Nishida E: A mitogen-activated protein (MAP) kinase activating factor in mammalian mitogen-stimulated cells is homologous 
to Xenopus M phase MAP kinase activator. $J$ Biol Chem 1992; 267: 16685-16690.

28. Lowry $\mathrm{OH}$, Rosebrough NJ, Farr AL, Randall RJ: Protein measurement with the Folin phenol reagent. $J$ Biol Chem 1951; 193: 265-275.

29. Fishman JB, Dickey BF, Bucher NL, Fine RE: Internalization, recycling, and redistribution of vasopressin receptors in rat hepatocytes. J Biol Chem 1985; 260: $12641-12646$.

30. Kusaka I, Ishikawa S, Higashiyama $M$, Saito $T$, Nagasaka S, Saito T: The activation of phospholipase $\mathrm{D}$ participates in the mitogenic action of arginine vasopressin in cultured rat glomerular mesangial cells. Endocrinology 1996; 137: 5421-5428.

31. Itoh $\mathrm{H}$, Mukoyama $\mathrm{M}$, Pratt RE, Gibbons $\mathrm{GH}$, Dzau VJ: Multiple autocrine growth factors modulates vascular smooth muscle cell growth response to angiotensin II. J Clin Invest 1993; 91: 2268-2274.

32. Gibbons GH, Pratt RE, Dzau VJ: Vascular smooth muscle cell hypertrophy vs. hyperplasia: autocrine transforming growth factor- $\beta_{1}$ expression determines growth response to angiotensin II. J Clin Invest 1992; 90: $456-461$.

33. Kanai H, Mitsuhashi H, Ono K, Yano S, Naruse T:
Increased excretion of urinary transforming growth factor $\beta$ in patients with focal glomerular sclerosis. Nephron 1994; 66: 391-395.

34. Yamamoto T, Noble NA, Cohen AH, et al: Expression of transforming growth factor- $\beta$ isoforms in human glomerular diseases. Kidney Int 1996; 49: 461469.

35. Tamaki K, Okuda S, Nakayama M, Yanagida T, Fujishima $M$ : Transforming growth factor- $\beta 1$ in hypertensive renal injury in Dahl salt-sensitive rats. $J$ Am Soc Nephrol 1996; 7: 2578-2589.

36. Ziyadeh FN, Sharma K, Ericksen M, Wolf G: Stimulation of collagen gene expression and protein synthesis in murine mesangial cells by high glucose is mediated by autocrine activation of transforming growth factor- $\beta$. J Clin Invest 1994; 93: 536-542.

37. Okuda S, Languino LR, Ruoslahti E, Border WA: Elevated expression of transforming growth factor- $\beta$ and proteoglycan production in experimental glomerulonephritis. J Clin Invest 1990; 86: 453-462.

38. Wolf G, Chen KS, Ericksen M, Ziyadeh FN: High glucose-induced proliferation in mesangial cells is reversed by autocrine TGF- $\beta$. Kidney Int 1992; 42: 647-656. 